\title{
Application of principal components analysis to the study of salinization on the Castellon Plain (Spain)
}

\author{
I. Morell,* E. Giménez, M.V. Esteller \\ Environment and Natural Resources Group, Dept. of Experimental Sciences, Jaume I University, P.O. Box 224, \\ 12080 Castellon, Spain
}

Received 3 February 1995; accepted 9 June 1995

\begin{abstract}
The high salinization in some sectors of the Castellon Plain aquifer (Spain) has been erroneusly attributed to scawater intrusion, because of the high and increasing contents of chloride ions. However, recent studies of this aquifer have shown that the chemical characteristics of groundwaters are the result of three different components: intruding seawater, freshwater from rainfall infiltration and saline water with a characteristic sulphate-calcium-magnesium facies, derived from bordering aquifers. The division into sectors according to hydrochemical features, in addition to the inclusion as variables of both certain minor ions and the ionic deviations of the theoretical mixing of freshwater and seawater, have provided a clear characterization of the salinization processes affecting the aquifer. The present study shows the application of statistical methods to the characterization of the salinization processes in the coastal aquifer of the Castellon Plain. The application of these statistical methods (cluster analysis and principal components analysis) has lead to the corroboration of the hypotheses developed from the previous hydrochemical study. Inclusion of specific variables (certain minor ions and ionic- $\Delta$ ) into the PCA enhances a definition of the degree of the salinization processes.
\end{abstract}

Keywords: Groundwater salinization; Castellon Plain, Spain; Principle components analysis (PCA); Cluster analysis

\section{Introduction}

In coastal aquifers, the hydrochemical differentiation of the salinization processes is very complex as there is considerable hydrochemical variability due to superposition of different processes: marine intrusion, continental salt water contribution and pollution phenomena. The Castellon Plain aquifer (Spain) is a good example

\footnotetext{
${ }^{*}$ Corresponding author.
}

of this problem. In these cases, statistical methods can be a useful tool to confirm and discriminate the influence of each of them on the final chemical composition of groundwater.

The analysis of multivariate data is used for classifying the variables and observational units and defining the relationship between them. The classification procedures are the hierarchical and non-hierarchical cluster analysis and discriminant analysis. The goal of these techniques is to quantify those statistical parameters that differentiate groups from previous data. 
Multiple regression, principal components and factor analyses are used for establishing relations of interdependence. The aim of these techniques is to establish the relationship between variables and define the contribution of each of them, or each combination, to the structure of hydrochemical data. Principal components analysis (PCA) is a method complementary to classical approaches for hydrogeochemical research. In the case of hydrochemical studies, these techniques can be used for distinguishing different processes of pollution (Melloul and Collin, 1992). In our case, salinization processes affecting the Castellon Plain aquifer were previously identified
(Fidelibus et al., 1992; Giménez, 1994), but the application of PCA techniques has improved the definition degree, identifying certain hydrochemical features which were not clear before.

\section{Definition of the problem}

The Castellon Plain (Fig. 1) is a tectonic coastal depression, located at the southeastern part of the Iberic Range, formed of conglomerates, sands and clays. These deposits are lenticular and irregular as a result of their torrential and fluvial origin; the fine fraction increases with depth.

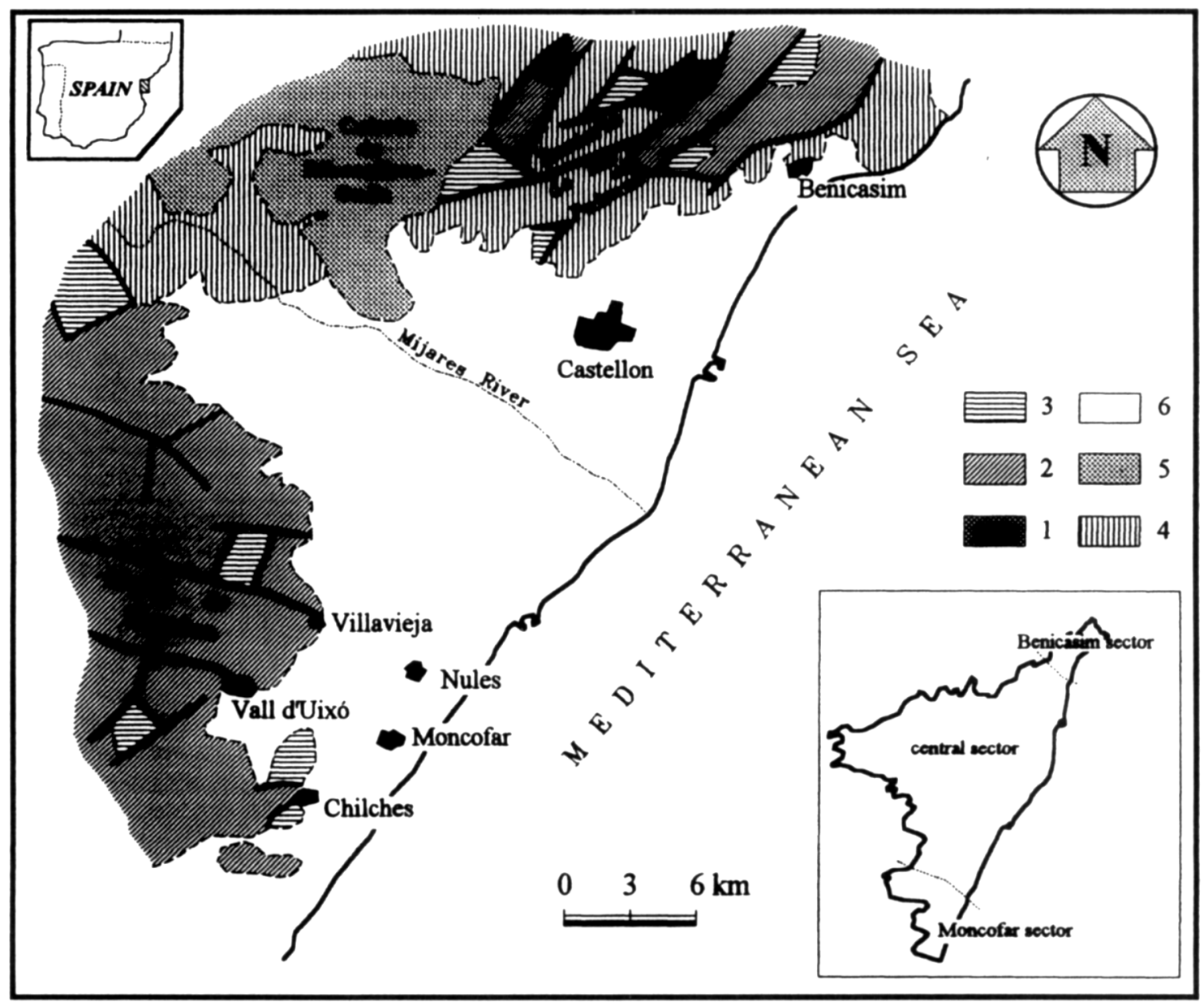

Fig. 1. Geological outline of the Castellon Plain and its surroundings (modified from Diputación de Castellón-IGME, 1988). 1, Paleozoic; 2, Triassic; 3, Jurassic; 4, Cretaceous; 5, Tertiary; 6, Plio-Quaternary. 
The Castellon Plain is bordered by Mesozoic hills to both north (Desierto de las Palmas) and south (Sierra de Espadán); the Miocene deposits of the Cubeta de Ribesalbes-Onda graben are the limit in the western part. The only permanent watercourse is the Mijares River which is used for irrigation in the central sector of the Plain.

The Plio-Quaternary formation of the CastelIon Plain is a major sedimentary aquifer, whose permeability is due to intergranular porosity. The unit overlies Mesozoic deposits that comprise a second aquifer, and over Miocene sediments of variable permeability, which occasionally constitute an aquiclude separating both aquifers.

The maximum transmissivity values are recorded in the areas of greatest saturated thickness, ranging between 500 and $6000 \mathrm{~m}^{2} /$ day. The maximum values are found in the central area (Mijares River) and Nules-Vall d'Uixö-Moncofar area. The lowest transmissivity values are registered in Chilches $\left(<1000 \mathrm{~m}^{2} /\right.$ day $)$ and Benicasim ( $<500-1000 \mathrm{~m}^{2} /$ day) sectors.

The salinization affecting this aquifer was identified in the 1970 s as being related to seawater intrusion (IGME, 1972). Recently (Fidelibus et al., 1992; Giménez, 1994), other mechanisms have been proposed to contribute to groundwater salinity, such as the sulphate waters coming from the border aquifer. The relative influence of each of these processes determines the existence of areas in which specific hydrochemical characteristics can be distinguished. Three sectors can be differentiated on the Castellon Plain: Benicasim, Moncofar and the Central Sector, the highest salinization levels being found in the two former sectors. In the Benicasim Sector, the waters have sodium chloride facies, with a low $\mathrm{SO}_{4}^{2-} / \mathrm{Cl}^{-}$ ratio and an average of $3 \%$ seawater. In the Central Sector the water is of a calcium-magnesium bicarbonate-sulphate type, with a high $\mathrm{SO}_{4}^{2-} / \mathrm{Cl}^{-}$ratio, with generally $<1 \%$ seawater. In the Moncofar Sector, the water is sulphatechloride magnesium-calcium, with an intermediate $\mathrm{SO}_{4}^{2-} / \mathrm{Cl}^{-}$ratio, and between $1 \%$ and $7 \%$ seawater.

The waters of the Castellon Plain aquifer can be associated with the mixture of the three water types: calcium bicarbonate, seawater and a third component characterized principally by a high sulphate content (Fidelibus et al., 1992; Giménez, 1994). In relation to the theoretical mixture between freshwater and seawater, the waters of the aquifer are rich in $\mathrm{SO}_{4}^{2-}, \mathrm{Ca}^{2+}$ and $\mathrm{Mg}^{2+}$, with $\mathrm{Na}^{+}$and $\mathrm{K}^{+}$concentrations at normally less than the theoretical values, calculated from chloride concentration which is considered as a conservative parameter. The differences between the observed and expected concentrations are expressed as $\Delta$ ion (in mequiv./1).

The increases in the sulphate ion can be assigned to the influence of water with sulphate facies and to the use of fertilizers on the land, though the latter is of less importance. The processes of ion exchange appear to be significantly involved in the chemical composition of the aquifer waters. The sedimentary nature of the aquifer, and the abundance of clays (illite, smectites, kaolinite) intensify the process, which is also more evident as the $\mathrm{Cl}^{-}$concentration increases. The $\Delta \mathrm{Ca}^{2+}$ and $\Delta \mathrm{Mg}^{2+}$ are assumed to be due principally to the influence of ion exchange processes with $\mathrm{Na}^{+}$and $\mathrm{K}^{+}$. This increase is also possibly related to sulphate water recharge and agricultural pollution could explain a part of the $\Delta \mathrm{Ca}^{2+}$.

The $\mathrm{Na}^{+}$and $\mathrm{K}^{+}$losses, in relation to the mixture of freshwater and seawater, are attributed to ion exchange with the $\mathrm{Ca}^{2+}$ ion. In the most southerly sector of Moncofar (Chilches), however, $\mathrm{K}^{+}$values are rather high, attributable to the influence of the sulphate waters which could be eventually enriched in this ion. With respect to the precipitation-dissolution processes of carbonates, the waters show a variable degree of saturation according to the proportion of seawater in the mixture. Thus, the most oversaturated waters are principally in the subsector of Chilches where the sulphate component has the strongest influence.

Bromide ions can be considered as an alternative tracer for the seawater intrusion in the aquifer of the Castellon Plain (Morell, 1985; Morell et al., 1986, 1988; Giménez and Morell, 1990, 1991), although its value is mainly qualitative. Increases in iodide, in relation to the line representing the seawater-freshwater mixing, are attributable to 
differential influxes from contiguous aquifers or to characteristics typical of the Plio-Quaternary aquifer, possibly dependent on the content of organic matter in the aquifer matrix. Boron can be a good indicator of salinization in the Castellon Plain (Giménez and Morell, 1992), but the high contents of boron detected in some waters of the central sector appear due to the pollution produced by industrial and urban sources.

The high $\Delta \mathrm{Li}^{+}$and $\Delta \mathrm{Sr}^{2+}$ values in the area around Moncofar are related to local influxes rich in these ions. The fact that these influxes occur in the area with the highest values for sulphate ions suggests that magnesium-calcium-sulphate waters have remained in contact with the aquifer matrix for a long period, during which there was an enrichment in these ions. The abundance of $\mathrm{Li}^{+}$ and the presence of thermal waters in Villavieja $\left(48^{\circ} \mathrm{C}\right.$ ), drained by the Muschelkalk (Middle Triassic) aquifer, indicate the possibility that the temperature of these influxes is comparatively high.

These waters, of relatively deep flow, can make contact with the most superficial levels, when over-exploitation of the Plio-Quaternary aquifer is extreme. It appears possible that the intense exploitation of this aquifer causes the concomitant lateral intrusion of seawater and the rise of the waters which normally flow at deep levels. The importance of each of these processes depends on the characteristics of the aquifer itself, hence the most permeable areas facilitate the entry of the seawater (Benicasim and MoncofarVall d'Uixó sectors), while in the less permeable sectors, where the thickness of the formation is also less, the exploitation of the most superficial levels can preferentially cause influx of the deep sulphate flow (Moncofar-Chilches sector).

\section{Discussion of the general hydrochemical patterns}

A study of the geochemical variables has provided a general hydrochemical characterization of the aquifer subsystem of the Castellon Plain. The statistical analysis applied (STATGRAF, Statistical Graphics Corporation, 1986) verifies the hydrochemical trends established by other tech- niques, evaluating the fundamental factors governing the general behaviour of the system.

The statistical multivariate treatment based on cluster analysis and principal component analysis (PCA) has been applied to both variables (physico-chemical parameters) and observations (samples) corresponding to sampling made in December 1990. The principal component analysis has been applied also to a second sampling (January, 1992). In the first sampling, special attention was given to the more coastal areas where seawater intrusion had been detected. Hydrogeochemical considerations led to an intensification of the second sampling in those areas in which high sulphate content was found.

\subsection{Cluster analysis}

Cluster analysis is the name given to a bewildering assortment of techniques designed to perform classification by assigning observations to groups so each group is more or less homogeneous and distinct from other groups (Davis, 1986).

In this work, cluster analysis has been applied to 43 observations, corresponding to the December 1990 sampling, in which conductivity, pH, chloride, sulphate, nitrate, sodium, calcium, magnesium, potassium and strontium were determined. The matrix of similarity based upon the correlation coefficients used for cluster analysis between variables is given in Table 1, and in Fig. 2 , the dendrogram. Two main groups can be distinguished: the first one formed by sulphate and calcium and partially potassium, characterizes the recharge of sulphate waters coming from the Triassic aquifers. The second group involves principally conductivity, chloride and sodium ions. Magnesium and strontium also belong to this group, which is assumed to have a marine origin. The remaining variables, $\mathrm{pH}$ and bicarbonate, have a very low correlation degree with both groups.

In Fig. 3, the dendrogram corresponds to the cluster between observations. Two different families are distinguished: the first one, formed by the more saline points, located in coastal sectors of Moncofar and Benicasim, and the second, with lowest salinity, including the rest of the observa- 
Table 1

Correlation matrix between variables, December 1990

\begin{tabular}{|c|c|c|c|c|c|c|c|c|c|c|c|}
\hline & Conductivity & $\mathrm{pH}$ & $\mathrm{Cl}^{-}$ & $\mathrm{HCO}_{3}^{-}$ & $\mathrm{SO}_{4}^{2-}$ & $\mathrm{NO}_{3}^{-}$ & $\mathrm{Na}^{+}$ & $\mathrm{Ca}^{2+}$ & $\mathrm{Mg}^{2+}$ & $\mathrm{K}^{+}$ & $\mathrm{Sr}^{2+}$ \\
\hline Conductivity & 1.00 & & & & & & & & & & \\
\hline $\mathrm{pH}$ & 0.16 & 1.00 & & & & & & & & & \\
\hline $\mathrm{Cl}^{-}$ & 0.94 & 0.21 & 1.00 & & & & & & & & \\
\hline $\mathrm{HCO}_{3}^{-}$ & 0.21 & -0.04 & 0.25 & 1.00 & & & & & & & \\
\hline $\mathrm{SO}_{4}^{2-}$ & 0.48 & 0.08 & 0.26 & -0.15 & 1.00 & & & & & & \\
\hline $\mathrm{NO}_{3}^{-}$ & 0.49 & -0.07 & 0.42 & -0.01 & 0.02 & 1.00 & & & & & \\
\hline $\mathrm{Na}^{+}$ & 0.89 & 0.28 & 0.92 & 0.32 & 0.25 & 0.32 & 1.00 & & & & \\
\hline $\mathrm{Ca}^{2+}$ & 0.56 & 0.08 & 0.4 & -0.14 & 0.86 & 0.28 & 0.31 & 01.00 & & & \\
\hline $\mathrm{Mg}^{2+}$ & 0.84 & 0.06 & 0.83 & 0.41 & 0.28 & 0.48 & 0.74 & 0.29 & 1.00 & & \\
\hline $\mathbf{K}^{+}$ & 0.38 & 0.00 & 0.2 & -0.07 & 0.61 & -0.19 & 0.24 & 0.51 & 0.06 & 1.00 & \\
\hline $\mathrm{Sr}^{2+}$ & 0.67 & 0.00 & 0.57 & 0.19 & 0.49 & 0.33 & 0.64 & 0.62 & 0.41 & 0.41 & 1.00 \\
\hline
\end{tabular}

tions. The first family can be separated into two groups, clearly representing the samples from Benicasim and Moncofar. In the Moncofar group, other clusters containing the samples from Moncofar-Vall d'Uix (M.1) and Moncofar-Chilches (M.2) are differentiated as a result of the relative influence of marine intrusion and sulphate water recharge. From these considerations, it seems obvious that the grouping responds to salinity criteria.

\subsection{Principal component analysis}

PCA has been used frequently in geochemical studies (Pulido et al., 1988; Deverel, 1989; Navarro, 1991; Arrate et al., 1992; Melloul and Collin, 1992; Olias and Cruz, 1992). The most distinctive aspect of PCA is its data reduction

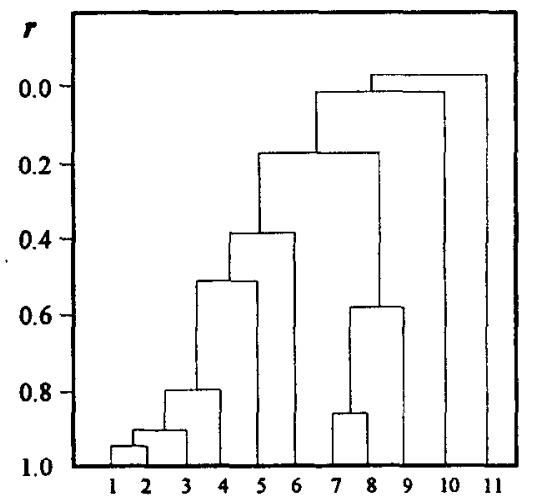

Fig. 2. Dendrogram of cluster analysis between variables, December 1990. 1, Conductivity; $2, \mathrm{Cl}^{-} ; 3, \mathrm{Na}^{+} ; 4, \mathrm{Mg}^{2+} ; 5$, $\mathrm{Sr}^{2+} ; 6, \mathrm{NO}_{3}^{-} ; 7, \mathrm{SO}_{4}^{2-} ; 8, \mathrm{Ca}^{2+} ; 9, \mathrm{~K}^{+} ; 10, \mathrm{pH} ; 11, \mathrm{HCO}_{3}^{-}$. capability. Factor analysis is used to transform the initial data matrix into a new set of composite variables or principal components. This technique is employed to visualize similarities between variables in wells which have been sampled.

This analysis has been used for both sampling periods (December 1990 and January 1992) using the variables chloride, bicarbonate, sulphate, nitrate, sodium, calcium, magnesium, potassium and strontium, with the addition of lithium, boron, bromide and iodide in the second sampling.

From the similarity matrix, the principal components have been determined. Component I, representing the first axis, explains as much as possible of the total variance of the observations, and accounts for $45 \%$ of the variation in the data. The second component, representing the second axis, explains as much as possible of the residual variance $(23 \%)$.

Spatial distribution according to the two first components (Fig. 4) shows that the first component discriminates in terms of salinity and the second component differentiates ion groupings representing seawater intrusion $\left(\mathrm{Cl}^{-}, \mathrm{Na}^{+}\right.$and $\left.\mathrm{Mg}^{2+}\right)$ and sulphate water $\left(\mathrm{SO}_{4}^{2-}, \mathrm{Ca}^{2+}\right.$ and $\left.\mathrm{K}^{+}\right)$ influence, respectively.

Distribution of observation points with respect to components I and II is shown in Fig. 5. Corroborating the results obtained by the cluster analysis, the groups formed by the samples from Benicasim and Moncofar are clearly distinguished. The rest of the observations belong to the Central sector of the aquifer with lower salin- 


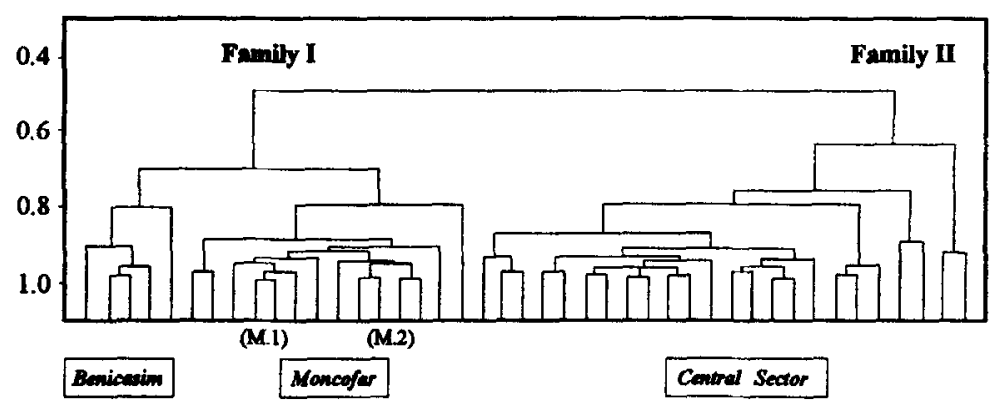

Fig. 3. Dendrogram of cluster analysis between observations, December 1990. M.1, MoncÓfar-Vall d’Uixó; M.2, Moncófar-Chilches.

ity. Thus, the first component distinguishes groups of different salinity, whereas the second component could discriminate the observations from the sulphate content, but not in a clear way.

In order to know more clearly the relative influence of the salinization processes, a second sampling was carried out in January 1992, with a larger number of samples from the MoncofarChilches area, where the effect of sulphate water flow seems to be more evident.

Thirteen variables were studied in the January 1992 sampling $\left(\mathrm{Cl}^{-}, \mathrm{HCO}_{3}^{-}, \mathrm{SO}_{4}^{2-}, \mathrm{NO}_{3}^{-}, \mathrm{Ca}^{2+}\right.$, $\mathrm{Mg}^{2+}, \mathrm{Na}^{+}, \mathrm{K}^{+}, \mathrm{Li}^{+}, \mathrm{Sr}^{2+}, \mathrm{B}, \mathrm{Br}^{-}$and $\left.\mathrm{I}^{-}\right)$. The data for these variables have been standarized and the variation in the data has been weighted in relation to the first two components.

At the same time, a study was made of the correlations between the different parameters, providing the coefficients presented in Table 2.

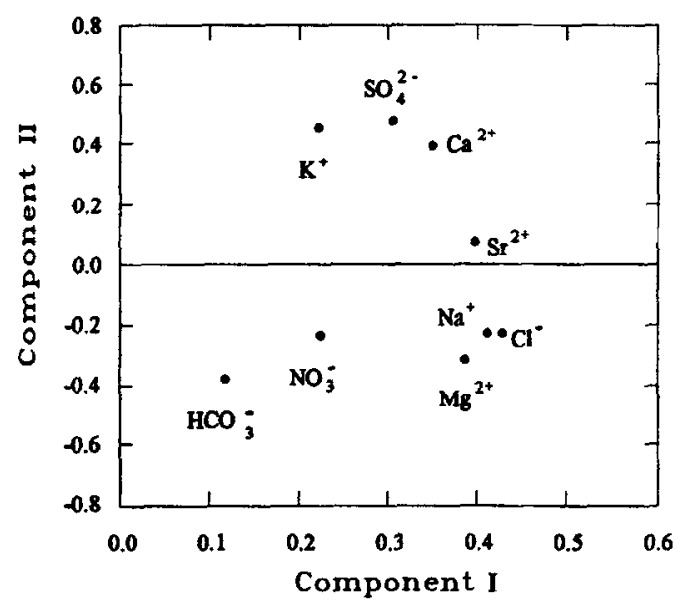

Fig. 4. Behaviour of the variables with respect to the first two components, December 1990.
This analysis discriminates the fundamental variables determining the evolution patterns of the waters studied, as well as the relationship of these patterns with the rest of the variables or with the processes identified in the aquifer. Of note are the high correlation coefficients between the $\mathrm{Cl}^{-}$ and $\mathrm{Br}^{-}$variables $(0.98)$ and between the concentrations of $\mathrm{Sr}^{2+}$ and $\mathrm{Li}^{+}(0.78)$; simultaneously, the relationship between each of the first group variables $\left(\mathrm{Cl}^{-}\right.$and $\left.\mathrm{Br}^{-}\right)$and the second group $\left(\mathrm{Sr}^{2+}\right.$ and $\left.\mathrm{Li}^{+}\right)$, is defined by the relatively low correlation coefficients $(0.16-0.33)$. These facts, together with the evolution trends defined in the basic hydrochemical study, lead to a series of preliminary considerations: the concentrations of $\mathrm{Cl}^{-}$and $\mathrm{Br}^{-}$can be considered as the variables describing the process of seawater intrusion, while the variables $\mathrm{Sr}^{2+}$ and $\mathrm{Li}^{+}$can be identified as representative of an alternative salinization

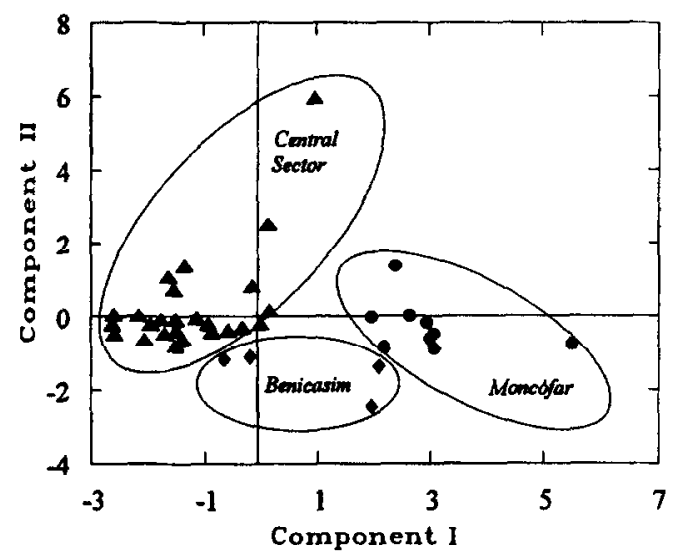

Fig. 5. Distribution of the observation points with respect to the first two components, December 1990. 
Table 2

Correlation coefficients between variables, January 1992

\begin{tabular}{|c|c|c|c|c|c|c|c|c|c|c|c|c|c|}
\hline & $\mathrm{Cl}^{-}$ & $\mathrm{HCO}_{3}^{-}$ & $\mathrm{SO}_{4}^{2-}$ & $\mathrm{NO}_{3}^{-}$ & $\mathrm{Ca}^{2+}$ & $\mathrm{Mg}^{2+}$ & $\mathrm{Na}^{+}$ & $\mathbf{K}^{+}$ & $\mathrm{Li}^{+}$ & $\mathrm{Sr}^{2+}$ & B & $\mathrm{Br}^{-}$ & $\mathbf{I}^{-}$ \\
\hline $\mathrm{Cl}^{-}$ & 1.00 & & & & & & & & & & & & \\
\hline $\mathrm{HCO}_{3}^{-}$ & -0.03 & 1.00 & & & & & & & & & & & \\
\hline $\mathrm{SO}_{4}^{2-}$ & 0.47 & 0.19 & 1.00 & & & & & & & & & & \\
\hline $\mathrm{NO}_{3}^{-}$ & 0.44 & -0.21 & 0.46 & 1.00 & & & & & & & & & \\
\hline $\mathrm{Ca}^{2+}$ & 0.78 & -0.24 & 0.71 & 0.66 & 1.00 & & & & & & & & \\
\hline $\mathrm{Mg}^{2+}$ & 0.76 & 0.10 & 0.58 & 0.48 & 0.71 & 1.00 & & & & & & & \\
\hline $\mathrm{Na}^{+}$ & 0.88 & 0.09 & 0.48 & 0.32 & 0.60 & 0.50 & 1.00 & & & & & & \\
\hline $\mathrm{K}^{+}$ & 0.31 & 0.11 & 0.55 & 0.04 & 0.39 & 0.27 & 0.36 & 1.00 & & & & & \\
\hline $\mathrm{Li}^{+}$ & 0.30 & 0.30 & 0.62 & 0.35 & 0.50 & 0.39 & 0.30 & 0.67 & 1.00 & & & & \\
\hline $\mathrm{Sr}^{21}$ & 0.33 & 0.24 & 0.64 & 0.31 & 0.59 & 0.38 & 0.30 & 0.48 & 0.78 & 1.00 & & & \\
\hline B & 0.42 & 0.20 & 0.42 & 0.26 & 0.40 & 0.40 & 0.43 & 0.33 & 0.13 & 0.16 & 1.00 & & \\
\hline $\mathrm{Br}^{-}$ & 0.98 & -0.78 & 0.40 & 0.40 & 0.74 & 0.75 & 0.84 & 0.20 & 0.16 & 0.24 & 0.40 & 1.00 & \\
\hline $\mathrm{I}^{-}$ & 0.32 & 0.09 & 0.38 & 0.36 & 0.24 & 0.39 & 0.33 & 0.24 & 0.12 & -0.03 & 0.65 & 0.32 & 1.00 \\
\hline
\end{tabular}

process (sulphate waters). Both groupings define the salinity of the waters, by one process or the other.

With respect to the other factors, it is notable that the relationships between the $\mathrm{SO}_{4}^{2-}$ concentration and the pairs $\mathrm{Cl}^{-}+\mathrm{Br}^{-}$and $\mathrm{Sr}^{2+}+\mathrm{Li}^{+}$ are defined by correlation coefficients $0.47-0.40$ and $0.62-0.64$, respectively. These relationships can be attributed to the fact that the $\mathrm{SO}_{4}^{2-}$ ion may be associated with the two salinization processes, defined respectively by the two pairs. At the same time, the relationships $\mathrm{SO}_{4}^{2-}$ to $\mathrm{Ca}^{2+}$ and $\mathrm{SO}_{4}^{2-}$ to $\mathrm{Mg}^{2+}$ show relatively high correlation levels ( 0.71 and 0.58 , respectively).

The correlations $\mathrm{Cl}^{-}$to $\mathrm{Na}^{+}(0.88)$ and $\mathrm{Cl}^{-}$to $\mathrm{Mg}^{2+}(0.88)$ are thus significant, and attributable to seawater intrusion significantly raising the concentration of these ions in the water. The coefficient between $\mathrm{Ca}^{2+}$ and $\mathrm{Mg}^{2+}(0.71)$ may verify the relationship between the two cations, defined in the general hydrochemical study. Finally, the high correlation values between the concentrations of $\mathrm{Ca}^{2+}$ and $\mathrm{Cl}^{-}(0.78)$ can hardly be related with any of the salinization processes recognized, and only possibly with secondary processes such as ionic exchange, which becomes more evident in the more salinized water as the $\mathrm{Cl}^{-}$ concentration increases.

The relationship between $\mathrm{Ca}^{2+}$ and $\mathrm{NO}_{3}^{-}(0.66)$ could be due to the processes that occur after the application of nitrogenated fertilizers (mainly am- monium sulphate and ammonium nitrate), which add $\mathrm{Ca}^{2+}$ to the water, as a consequence of a likely ionic exchange between ammonium and calcium (Giménez, 1994).

Fig. 6 represents the behaviour of different variables with respect to the first two components, which account for $62.0 \%$ of the total variance of the data. With respect to Component $I$, the parameters corresponding to the $\mathrm{Cl}^{-}$and $\mathrm{SO}_{4}^{2-}$ concentration, the principle causes of the saline content in the waters, are located at the positive end of the abscissa axis, while the variable representative of the $\mathrm{HCO}_{3}^{-}$concentration has a charge coefficient of almost zero. This raises the possibility that the first component represents the saline evolution of the waters from fresher components to more saline ones. The second component differentiates ion groupings which can be attributed to the different processes determining the salinization of the waters. The variables $\mathrm{Cl}^{-}$and $\mathrm{Br}^{-}$, identified (as stated above) as tracers of seawater intrusion, appear, with respect to the second component, in the positive field, while the variables $\mathrm{Sr}^{2+}$ and $\mathrm{Li}^{+}$are identified in the more negative part of the axis. The discrimination between these parameters characterizes Component II as representative of the differentiation of the salinization processes in the Castellon Plain.

On analysing the distribution of the samples from the aquifer, with respect to these two components (Fig. 7), their grouping is recognizable in 


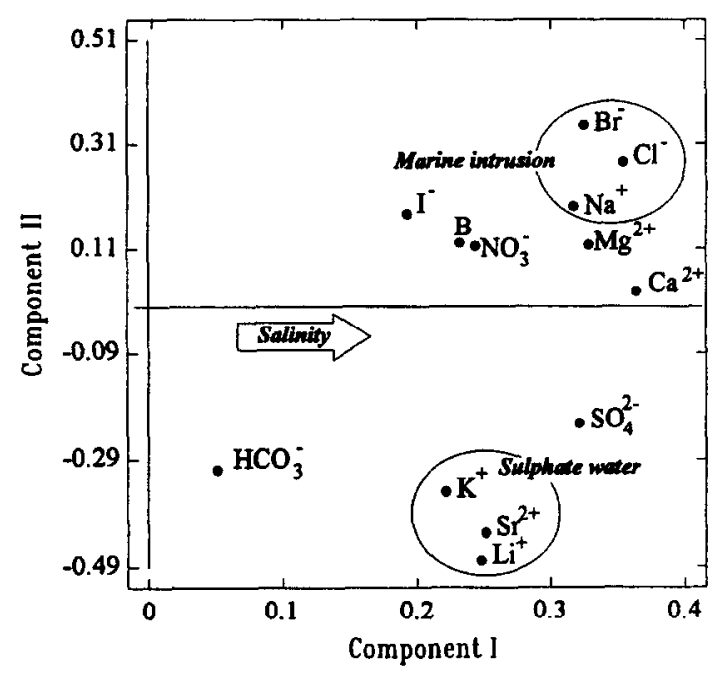

Fig. 6. Behaviour of the variables with respect to the first two components, January 1992.

the three sectors identified in the aquifer, in concordance with the proposed hydrochemical model. Concerning the influence of the two components considered in the discrimination of the samples, the first component appears to be funda- mental in separating the different degrees of salinity. Thus, Component I provides a clear differentiation of the samples of the central sector, with respect to the more salinized areas of the aquifer: Benicasim and Moncofar.

The second component allows the discrimination of two main groupings, the sectors of Benicasim and Moncofar, and, in the latter, two subsectors, Moncofar-Vall d'Uixó and MoncofarChilches. In Benicasim, the distribution of the points indicates the relationship of this sector with the process of seawater intrusion.

The distribution of the waters of the Moncofar sector, in relation to the first component, signifies the rise in salinity. The second component gives a parallel discrimination of the important groupings, in the positive and negative fields of the axis. The first of these corresponds to the waters taken from the northern area of the sector (subsector Moncofar-Vall d'Uixó), in which the salinity has been attributed to the lateral intrusion of seawater into the aquifer, and in fact its relationship with the variables representative of this process $\left(\mathrm{Cl}^{-}\right.$to $\left.\mathrm{Br}^{-}\right)$is recognized. The water distribution

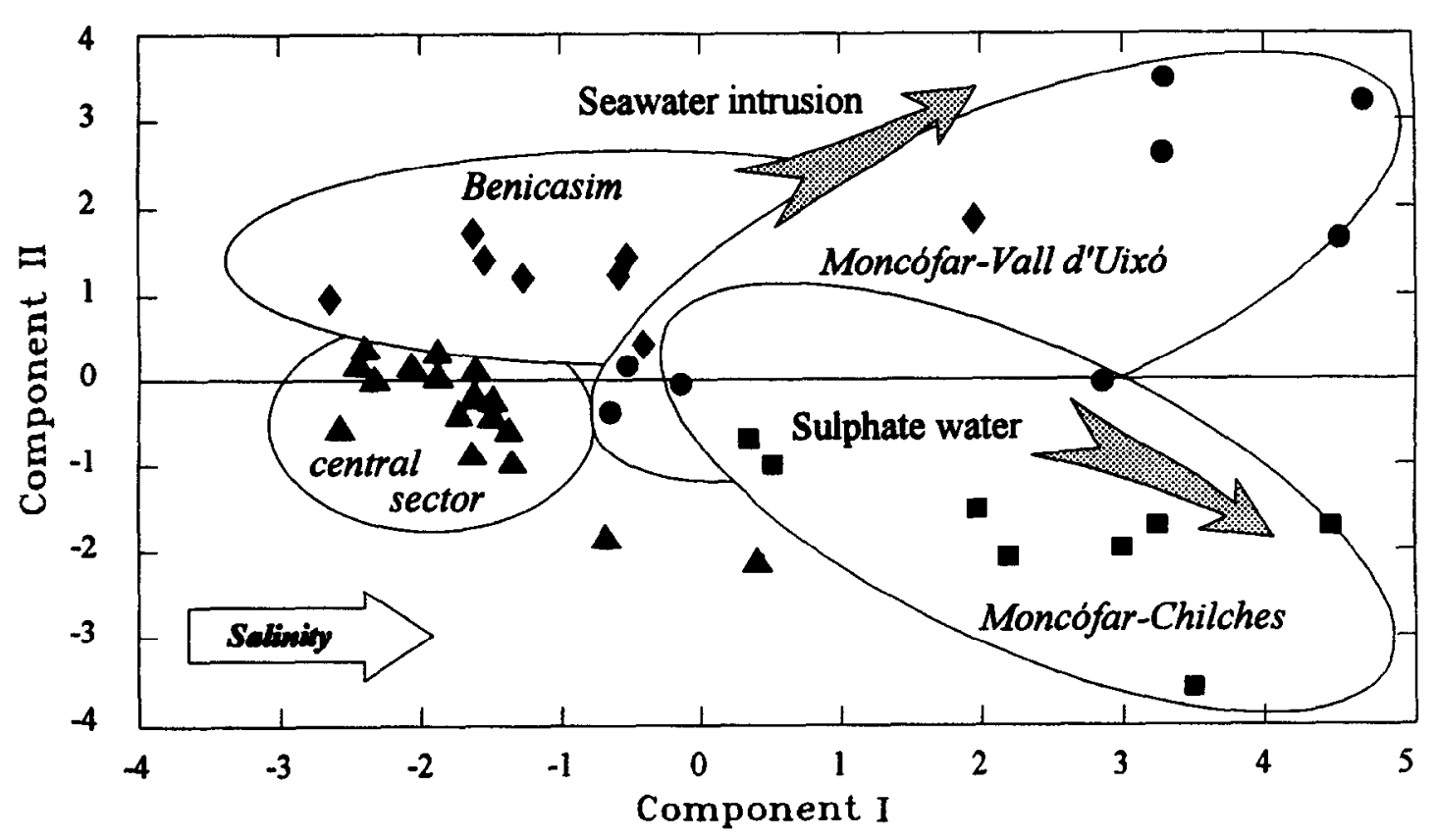

Fig. 7. Distribution of the observation points with respect to the first two components, January 1992. 
in the southern sector (Moncofar-Chilches) relates the salinity of these waters to the salinization process established by the variables $\mathrm{Sr}^{2+}$ and $\mathrm{Li}^{+}$, recognized as tracers of sulphate water. The sulphate ion cannot be used as a precise indicator of sulphate water, since this ion appears in two types of saline waters (seawater and sulphate water) and prevents it from being a tracer of a definite process. Therefore, the statistical treatment includes other variables which can define the system and its processes with greater clarity: the ionic $\Delta$ of the ions $\mathrm{SO}_{4}^{2-}, \mathrm{Ca}^{2+}, \mathrm{Mg}^{2+}, \mathrm{Li}^{+}$, $\mathrm{Sr}^{2+}, \mathrm{B}$ and $\mathrm{I}^{-}$, that is, the excesses with respect to the theoretic concentrations resulting from the simple mixing of fresh and seawater.

Fig. 8 shows the behaviour of these new variables with respect to the first two components, which explain $56.0 \%$ of the variance. The analysis again indicates that the first component should be read in terms of salinity. Regarding the second component, the introduction of the variables $\Delta \mathrm{SO}_{4}^{2-}, \Delta \mathrm{Li}^{+}$and $\Delta \mathrm{Sr}^{2+}$, enables these three parameters to be considered tracers of the presence of sulphate waters in the aquifer. In the positive part of the axis, the correlation continues between the variables $\mathrm{Cl}^{-}$and $\mathrm{Na}^{+}$, representative of the seawater intrusion. The rest of the parameters are distributed in the field of the

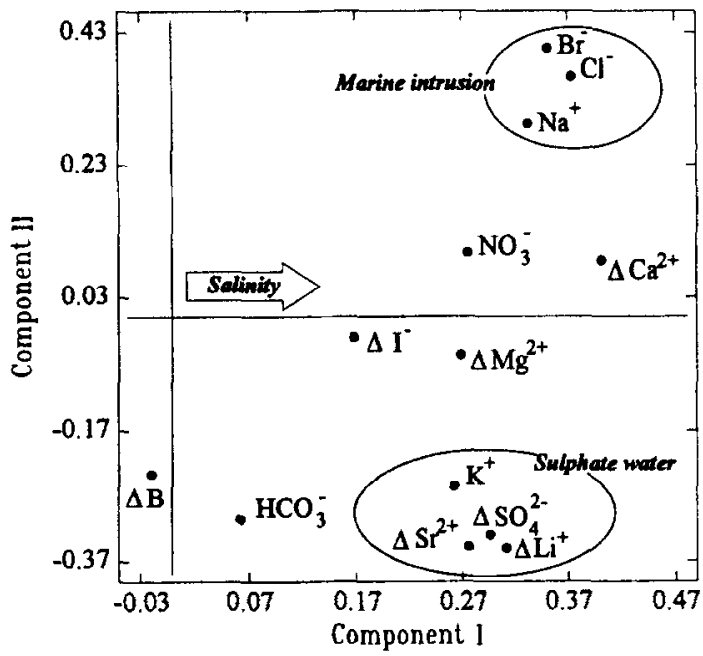

Fig. 8. Behaviour of the new variables (which include $\Delta \mathrm{SO}_{4}^{2-}$, $\Delta \mathrm{Ca}^{2+}, \Delta \mathrm{Mg}^{2+}, \Delta \mathrm{Li}^{+}, \Delta \mathrm{Sr}^{2+}, \Delta \mathrm{B}$, and $\left.\Delta \mathrm{I}^{-}\right)$with respect to the first two components, January 1992. coordinate axes, showing different degrees of dependence with the variables which identify the predominant processes.

The ionic groups distribution resulting from the analysis, and taking into account the ionic- $\Delta$, let us discriminate more clearly the two different types of salinization: marine intrusion and sulphate water flows. The relative influence of these processes has a different weight in each of the sectors of the aquifer (Benicasim, Central and Moncofar sectors). In order to calibrate this influence, a separate study has been carried out in each sector. In this case, the ionic- $\Delta$ values are not considered.

In Benicasim (Fig. 9), the two components account for $86.5 \%$ of the variation in the data. The distribution of the variables shows the increase in salt content, represented by the first component. Component II identifies two types of influxes: one related to the seawater intrusion (in the positive field of the axis) and the other, possibly related to the influxes of sulphate-bicarbonated waters, which would represent the freshest component. The $\mathrm{Li}^{+}$and $\mathrm{Sr}^{2+}$ ions, in this case, could be related directly to seawater intrusion; boron, however, appears to be linked to the less saline component recharging this part of the aquifer, but not to seawater contribution or pollution processes.

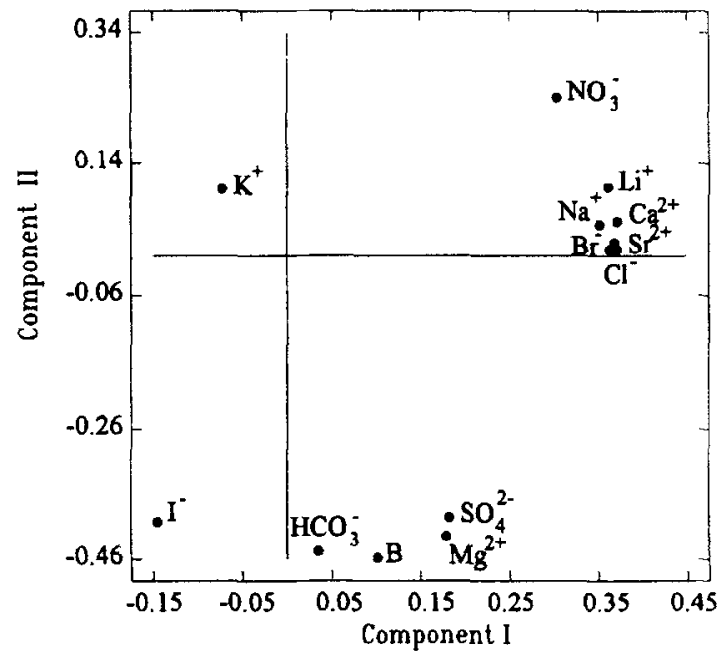

Fig. 9. Benicasim Sector. Distribution of the variables with respect to the first two components. 
In the central sector, the results are somewhat less clear; the slight influence of the salinization processes in the area hampers the interpretation, as there are no significant groupings. Fig. 10 represents the distribution of variables with respect to the first two components, which explain the $49.9 \%$ variance. The location of the variables $\mathrm{HCO}_{3}^{-}, \mathrm{SO}_{4}^{2-}, \mathrm{Ca}^{2+}$ and $\mathrm{NO}_{3}^{-}$in the negative part of Component $\mathrm{I}$, against the positive values of the variables $\mathrm{Na}^{+}, \mathrm{Cl}^{-}$and $\mathrm{Br}^{-}$, can be interpreted as indicative that the first group of variables represents the fresh component of the aquifer (these waters are characterized by a calcium bicarbonate-sulphate facies and this area has the highest $\mathrm{NO}_{3}^{-}$concentrations) and that, therefore, this first component continues to reflect the saline increase in the waters. The second component differentiates, with poor precision, the group $\mathrm{SO}_{4}^{2-}, \mathrm{Li}^{+}, \mathrm{Sr}^{2+}$, and $\mathrm{Mg}^{2+}$, representative of the sulphated component from those linked preferentially to agricultural pollution and to a marine intrusion.

In Fig. 11, corresponding to the sector of Moncofar, the study of the 13 variables with respect to the two principal components, accounts for $71.3 \%$ of the variation in the data. As in all the cases, the first component is clearly identified as representative of the salinity of the waters. The second component preferentially differentiates the two

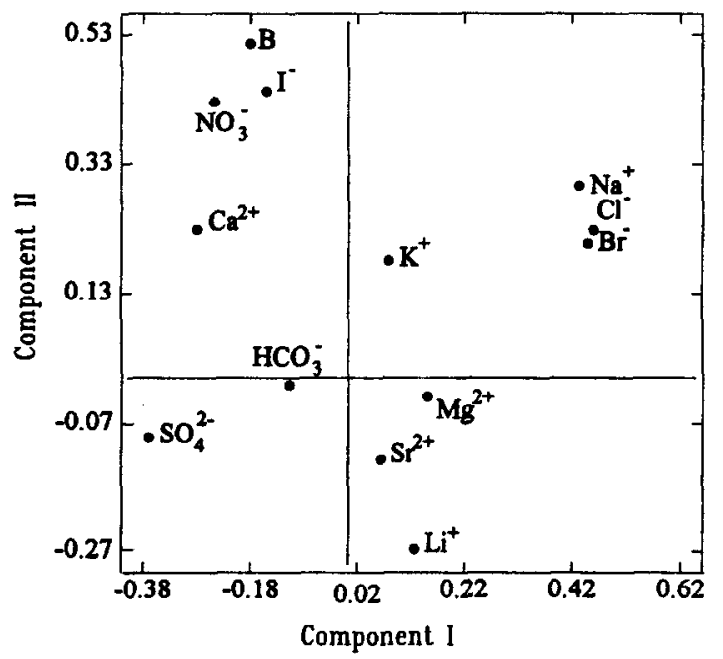

Fig. 10. Central Sector. Distribution of the variables with respect to the first two components.

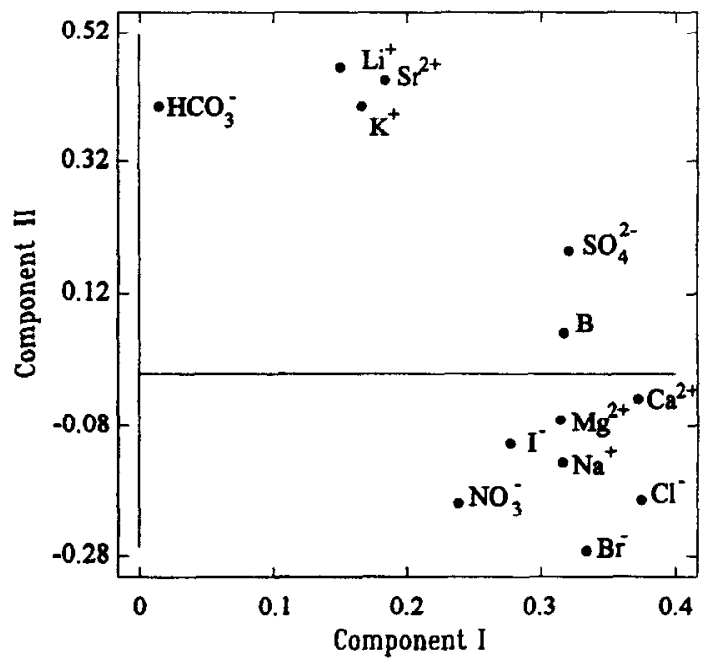

Fig. 11. Moncofar Sector. Distribution of the variables with respect to the first two components.

types of salinization defined in the sector, seawater intrusion and sulphate water, which are characterized by the variables $\mathrm{Li}^{+}, \mathrm{Sr}^{2+}$ and $\mathrm{K}^{+}$. It is worth bearing in mind that the hydrochemical study revealed that this latter ion increased in the waters of the southern sector (MoncofarChilches), presumably due to preferential influxes of sulphate waters. The intermediate position of the other variables with respect to the second component may be related to the entire set of processes which may be involved in the chemical evolution of the waters and which occur significantly in the sector.

\section{Conclusions}

PCA techniques are a valuable tool with an ability for identifying trends or distinctive features of processes with difficult hydrochemical characterization. The hydrogeochemical study of the Castellon Plain aquifer shows the existence of a complex mechanism of salinization in which seawater intrusion is not the only process affecting this aquifer but sulphate flows linked to Triassic aquifers contribute to increase the water salinity. The application of PCA techniques using only major ions roughly discriminates both salinization types. Inclusion of specific variables, such as certain minor ions $\left(\mathrm{Li}^{+}, \mathrm{Sr}^{2+}, \mathrm{B}, \mathrm{Br}^{-}, \mathrm{I}^{-}\right)$and $\Delta$ 
ionics of minor and major ions calculated with respect to theoretical mixing of freshwaterseawater, notably increases the definition degree of the variables and observation groups and shows the existence of superimposed processes which have to be justified from a hydrodynamic and geochemical point of view.

The more relevant contribution of PCA has been the discrimination in the southern sector of the aquifer where the Moncofar-Vall d'Uixö area is defined by parameters clearly related to seawater intrusion, whereas the Moncofar-Chilches area is mainly characterized by $\Delta \mathrm{Li}^{+}, \Delta \mathrm{Sr}^{2+}$ and $\Delta \mathrm{SO}_{4}^{2-}$, which suggest a common origin, linked to deep saline flows from the Triassic aquifers.

This differentiation has great importance in establishing guidelines for the management of resources and the improvement of the water quality.

\section{References}

Arrate, I., I. Morell and I. Antigüedad, 1992. Contaminación por nitratos en el acuífero cuaternario de Vitoria-Gasteiz: Distribución espacial y evolución temporal. Hidrogeología y Recursos Hidráulicos, XVI: 127-141.

Davis, J.C., 1986. Statistics and Data Analysis in Geology. Wiley, New York, p. 646.

Deverel, S.J., 1989. Geostatistical and principal components nalysis of ground water chemistry and sool-salinity data, San Joaquin Valley, California. In: IAHS (Publ.) Proceedings of the Baltimore Symposium (May 1989), Regional Characterisation of Water Quality, pp. 11-18.

Diputación de Castellón-IGME, 1988. Atlas Hidrogeológico de la provincia de Castellón. Diputación de Castellón, Castellón (Spain).

Fidelibus, M.D., E. Giménez, I. Morell and L. Tulipano, 1992. Salinization processes in the Castellon Plain aquifer. In: E. Custodio and A. Galofre (Eds.), Study and Modelling of Salt Water Intrusion into Aquifers. Proceedings of the 12th Saltwater Intrusion Meeting, Barcelona (Spain), pp. 267-284.

Giménez, E., 1994. Caracterización hidrogeoquímica de los procesos de salinización del acuífero detrítico costero de la Plana de Castellon. Tesis Doctoral, Universidad de Granada, p. 390.

Giménez, E. and I. Morell, 1990. El ión bromuro como indicador hidroquímico de la intrusión marina. IV Reunión Nacional de Geología Ambiental y Ordenación del Territorio, pp. 279-286.

Giménez, E. and I. Morell, 1991. Consideraciones sobre la utilización de iones minoritarios en la caracterización de la intrusión marina. El Agua en Andalucía, Vol. I, pp. 401-412. Córdoba (Spain).

Giménez, E. and I. Morell, 1992. Utilización del boro como indicador de contaminación en la Plana de Castellon. Hidrogeología y Recursos Hidráulicos, XVI: 285-292.

IGME, 1972. Informe Hidrogeológico preliminar de la Plana de Castellón. Ministerio de Industria y Energía Madird. (Juedit Report).

Melloul, A. and M. Collin, 1992. The 'principal components' statistical method as a complementary approach to geochemical methods in water quality factor identification; application to the Coastal Plain aquifer of Israel. J. Hydrol., 140: 49-73.

Morell, I., 1985. Caractcrización hidroquímica de la intrusión marina en la Plana de Oropesa-Torreblanca (Castellon). Tesis Doctoral, Universidad de Granada, p. 308.

Morell, I., J. Medina, A. Pulido and R. Fernandez-Rubio, 1986. The use of bromide and strontium ions as indicators of marine intrusion on the aquifer of Oropesa-Torreblanca (Castellon-Spain). Proceedings of the 9th Saltwater Intrusion Meeting, Delft, pp. 61-72.

Morell, I., E. Giménez and M.V. Esteller, 1988. Comportamiento iónico y procesos físico-químicos en acuíferos detríticos costeros de las planas de Oropesa, Castellon y Gandia. (Comunidad Valenciana). Hidrogeolog!a, 3: 21-33.

Navarro, A., 1991. Aplicación del Análisis de Componentes Principales (ACP) al estudio de los procesos de diferenciación hidroquímica en aguas subterráneas. Tecnología del Agua, 82: 69-80.

Olias, M. and J.J. Cruz, 1992. Aportación de los datos hidroquímicos al estudio de un caso de contaminación de aguas subterráneas por hidrocarburos. Hidrogeología y Recursos Hidráulicos, XVI: 441-454.

Pulido, A., F. Navarrete, J.L. Martinez, C. Alonso, A. Macias, L. Molina, J. Benavente, M. Chica and A. Padilla, 1988. Metodología del estudio de la intrusión marina del Campo de las Dalias (Almería). TIAC'88. Tecnología de la Intrusión en Acuíferos Costeros. Almuñecar (Granada), pp. 295-309. 